\title{
Stereotype Kulit Hitam dalam Iklan Deterjen Qiaobi 2016
}

\author{
Rezki Yoga Pamungkas \\ Program Studi Ilmu Komunikasi, Universitas Muhammadiyah Yogyakarta, Indonesia \\ rezki.yoga.isip19@mail.umy.ac.id \\ Nashiruddin Akmal \\ Program Studi Ilmu Komunikasi, Universitas Muhammadiyah Yogyakarta, Indonesia \\ nashiruddin.a.isip19@mail.umy.ac.id \\ Suriya Alqadri \\ Program Studi Ilmu Komunikasi, Universitas Muhammadiyah Yogyakarta, Indonesia \\ suriya.a.isip19@mail.umy.ac.id \\ Diserahkan: 14 Juni 2021; Direvisi: 28 Juni 2021; Diterima: 29 Juni 2021
}

\begin{abstract}
Qiaobi laundry detergent product is a clothing detergent brand that promotes its products through various media, one of which is television. However, after several months of being promoted through television media, this ad was removed by the Chinese government because it contained racist elements involving the black race. This article uses the semiotic theory of Roland Barthes because his theory can reveal the systems and rules that allow signs to have meaning. In addition, it can also share the meaning of the text and reach out to a wider range. The black race gets different treatment from society because it is influenced by the ideology of white supremacy, where whites are seen as superior and superior, compared to blacks who are considered inferior and not superior. This leads to a conclusion that people prefer and idolize whites than blacks, this is influenced by the ideology of white supremacy, where whites are seen as superior and superior, compared to blacks who are considered inferior and not superior.
\end{abstract}

Keywords: Qiaobi Detergent; Television Ads; Blacks; Racism

\begin{abstract}
Abstrak
Produk deterjen cuci Qiaobi merupakan merek deterjen pakaian yang mempromosikan produknya melalui beragam macam media, salah satunya media televisi. Tetapi, setelah beberapa bulan dipromosikan melalui media televisi, iklan ini dihapus oleh pemerintah Cina karena mengandung unsur rasis yang melibatkan ras kulit hitam. Artikel ini menggunakan teori semiotika dari Roland Barthes karena teorinya dapat mengungkap sistem dan aturan yang memungkinkan tanda memiliki makna. Selain itu juga dapat membagiisi makna teks dan menjangkau dengan waana yang lebih luas. Ras kulit hitam mendapatkan perlakuan berbeda dari masyarakat karena dipengaruhi oleh ideologi white supremacy, di mana kulit putih dipandang lebih superior dan unggul, dibandingkan kulit hitam yang dianggap inferior dan tidak unggul. Hal ini membuat sebuah kesimpulan kalau masyarakat lebih menyukai dan mengidolakan kulit putih dibandingkan kulit hitam, hal ini dipengaruhi oleh ideologi white supremacy, di mana kulit putih dipandang lebih superior dan unggul, dibandingkan kulit hitam yang dianggap inferior dan tidak unggul.

Kata Kunci: Deterjen Qiaobi; Iklan Televisi; Kulit Hitam; Rasisme
\end{abstract}




\section{PENDAHULUAN}

Saat ini pembicaraan mengenai warna kulit semakin hangat di kalangan wanita, perbandingan terhadap warna kulit tampaknya sudah menjadi topik yang popular terutama di media sosial dan media massa yang sering kita gunakan saat ini. Perkelompokan juga sering terjadi antara orang kulit putih yang membuat banyak orang kulit hitam menjadi terasingkan di circle tersebut.

Pemihakan terhadap, ras; seperti mengunggulkan ras kulit putih dibanding ras kulit hitam sudah sering terjadi, Pandangan bahwa warna kulit telah dianggap sebagai penanda utama dari identitas rasial yang sebenarnya dibentuk mempersepsikan adanya perbedaan, etnik, bahasa, kebangsaan, seksual dan kelas. "Ras" sebagai suatu konsep menerima makna-maknanya secara kontekstual, dalam hubungannya dengan kelompok-kelompok serta hierarki-hierarki sosial lainnya (Costanza-Chock, 2018).

Bahkan, hal ini sudah merambat di dunia entertainment, salah satunya adalah pembedaan terhadap warna kulit tampaknya sudah menjadi topik yang popular di bidang periklanan. Kulit putih selalu dihadirkan dalam sosok yang digambarkan sebagai pusat perhatian, menunjukkan bahwa pemeran atau model kulit putih begitu penting. Media melakukan naturalisasi terhadap kulit putih sebagai idealized beauty dalam konteks Indonesia. Hal ini dilakukan terutama dengan memanfaatkan teknologi fotografi, make up dan juga wacana yang dibangun di sekitar kulit putih.

Melalui audio seperti efek suara, narasi, dan musik lalu visual yang menarik dan kreatif dalam menggambarkan suatu produk membuat semakin menarik untuk dilihat dan mempersuasif penonton. Tak jarang iklan televisi juga bersifat reseptif dan berlebihan (Umarela et al, 2020).

Iklan televisi tidak ubahnya membongkar praktik ideologis yang bekerja secara manipulatif di dalam sebuah situasi sosial tertentu. Ideologi yang dimaksud mengacu pada suatu bentuk ideologis yang bertujuan untuk menarik perhatian melalui cara-cara seperti digunakan dalam teks (termasuk iklan televisi) sebagai produk media massa untuk mempresentasikan citra tertentu tentang dunia.(Umarela et al, 2020)

Dalam iklan televisi, sering dijumpai sejumlah iklan yang pemihakan pesan iklan kepada kelompok tertentu atau pada kelas yang berkuasa atau dominan. Kelas yang dimaksud bisa berkaitan dalam konteks ras. Menurut Liliweri (2003, p.92-93), stereotipe adalah evaluasi atau penilaian yang kita berikan kepada seseorang secara negatif, memiliki sifat-sifat yang negatif hanya karena keanggotaan orang itu pada kelompok tertentu. Sarwono-Meinarno dalam Pratama (2016, p.16) menyatakan kepercayaan tentang karakteristik dari anggota kelompok tertentu, bisa positif atau juga negatif. Stereotip positif kulit hitam adalah suka musik, cakap, suka olahraga, gemar bercerita, sensitif. Stereotipe negatif kulit hitam adalah percaya takhayul, malas, dungu, bodoh, kotor, naif, licik, agresif dan sombong (Nurhayati, 2019).

Penelitian berbeda yang dilakukan oleh Ancilla Evelyn, membahas tentang Representasi Ideologi Supremasi Kulit Putih dalam iklan Televisi, yang membahas tentang rasisme yang ada pada iklan Bukalapak Pengakuan: Awalnya coba - coba, jadi untung terus. Sedangkan penelitian kami membahas stereotip warna kulit yang terjadi pada iklan Deterjen Qiaobi. Iklan Deterjen ini mulai tayang pada April 2016 bercerita mengenai seorang wanita berkulit putih yang hendak mencuci pakaian lalu didatangi pria berkulit hitam yang ingin menggodanya.

\section{KAJIAN PUSTAKA}

\section{STEREOTYPES}

Kata "stereotypes" sendiri berasal dari gabungan dua kata Yunani, stereos yang berarti "solid" dan typos yang berarti "tanda pukulan". Sehingga kata - kata stereotype merujuk pada sesuatu yang solid dan memang arti awal dari istilah dalam Bahasa inggris mengacu pada pelat logam yang digunakan untuk mencetak halaman. Menurut Miller dalam buku The Psychology of Stereotyping, menjelaskan bahwa setidaknya timbul dua konotasi, yaitu kekakuan dan duplikasi atau kesamaan. Ketika diterapkan pada 
orang, maka stereotype itu kaku, dan mereka mencap semua yang mereka terapkan dengan karakter yang sama (Chaiklin, 2005).

Sementara itu James M. Jones dalam buku Racism, Sexism and Media, Stereotypes adalah sikap negatif terhadap seseorang atau kelompok berdasarkan proses perbandingan sosial di mana individu itu sendiri kelompok diambil sebagai titik acuan positif (Sataloff et al., 2013). Stereotypes dapat menjadi alat yang berguna bila digunakan tanpa prasangka. Seperti penjahat kulit putih yang dibawa ke pengadilan oleh pahlawan kulit putih di lingkungan sosial yang seluruhnya berkulit putih.

Hal tersebut merupakan pesan yang disampaikan kepada masyarakat adalah bahwa kebaikan mengalahkan kejahatan. Dalam mesin cuci yang sedang berputar. Setelah mesin cuci selesai bekerja pria berkulit hitam tadi keluar sebagai pria berkulit putih. Dalam iklan ini berarti bisa saja memiliki arti kalau pria berkulit hitam adalah kotor dan tidak disukai wanita berkulit putih. Sehingga bisa dikatakan bahwa dalam iklan tersebut terdapat unsur rasisme yang beranggapan bahwa kulit hitam itu tidak bersih dan menjijikkan.

Konstruksi masyarakat terhadap warna memberikan andil dalam membentuk pemikiran bahwa putih atau terang merepresentasi sesuatu yang suci, bersih, dan baik. Sementara itu, hitam atau gelap merepresentasi sesuatu yang kotor, jahat, dan tidak baik (Thompson, 2006:48). Tentu saja putih lebih disukai karena bernilai positif, sementara hitam tidak disukai karena dianggap bernilai negatif. Tidak mengherankan jika kemudian kulit putih diidolakan sementara kulit hitam dibenci (Evelyn et al., 2019).

Konstruksi seperti itu tentunya merugikan kulit hitam. Akan tetapi, sayangnya tidak sedikit masyarakat kulit hitam Amerika juga memiliki pemikiran yang sama tanpa menyadari bahwa hal tersebut sesungguhnya merendahkan martabat mereka. Masyarakat kulit hitam terhegemoni pandangan kulit putih. Hal ini terjadi karena masyarakat terpapar dengan ideologi kecantikan kulit putih (Evelyn et al., 2019).

Penelitian berbeda yang dilakukan oleh Ancilla Evelyn, membahas tentang Representasi Ideologi Supremasi Kulit Putih dalam iklan Televisi, yang membahas tentang rasisme yang ada pada iklan Bukalapak Pengakuan: Awalnya coba - coba, jadi untung terus. Sedangkan penelitian kami membahas stereotip warna kulit yang terjadi pada iklan Deterjen Qiaobi.

Namun, stereotypes negatif kelompok budaya non-kulit putih di lingkungan yang didominasi kulit putih menjadikan proses yang jauh berbeda jika dilakukan secara historis dan terus-menerus dengan prasangka (Sataloff et al., 2013).

Sementara itu, Hilton dan Von Vippel, dalam buku Psychology of Prejudice and Discrimanation, mengatakan stereotype adalah keyakinan dan pendapat tentang ciri, atribut, dan perilaku anggota dari berbagai kelompok (Kite \& Whitley, Jr., 2020). Masyarakat banyak mempelajari stereotypes dari media massa, teman mereka, orang tua, dan bahkan media sosial. Simbol media seperti ikon layar digital. Saat menggunakan komputer, laptop, tablet, atau ponsel,

Kita telah belajar bahwa ketika kita melihat ikon dan menunjuk ke sana, klik atau ketukan akan menghasilkan sesuatu yang kita inginkan ke layar. Simbol adalah ikon yang kita lihat di layar, dan stereotipnya adalah fungsi komputer menampilkan layar saat kita mengklik ikon. Dengan cara yang sama, gambar media tentang orang-orang dengan warna kulit non-putih, seperti pelayan Meksiko yang gemuk, penipu jalanan kulit hitam yang cerewet, kepala suku India, dan orang Asia sedang karate, telah menjadi simbol yang memicu stereotype orang-orang yang digambarkan dan orang lain yang terlihat seperti mereka (Sataloff et al., 2013) 


\section{RASISME}

Istilah 'racism' sendiri diciptakan pada tahun 1930-an, terutama sebagai tanggapan untuk proyek Nazi membuat judenrein Jerman, atau 'bersih dari orang Yahudi'. Nazi yakin bahwa orang Yahudi adalah ras yang berbeda dan menjadi ancaman bagi ras Arya yang dianggap berasal dari jerman asli (Maiti \& Bidinger, 1981).

Menurut Albach dan Lomotey dalam buku Racism, Discrimination and Prejudice, rasisme, prasangka, dan diskriminasi telah menjadi istilah yang akrab bagi mereka yang dianggap"kulit hitam". Dari pengenalan perbudakan Amerika pada tahun 1619 hingga upaya terorganisir untuk menempatkan status sosial yang lebih rendah pada orang kulit hitam selama era Jim Crow, pengalaman rasisme dan kejadian penindasan lainnya telah melanda orang - orang kulit hitam selama berabad - abad (Riley, 2011).

Melalui rasisme dan tindakan ketidakadilan sosial lainnya yang ada pada kulit hitam, membuat kelompok yang lebih dominan menciptakan pola historis dominasi dan subordinasi berdasarkan ras, hal ini menempatkan orang - orang kulit hitam sebagai bawahan dari orang - orang kulit putih yang tidak berdaya. Dikarenakan sifat subjektif dan kontekstual dari pengalaman rasis yang dialami orang - orang kulit hitam, rasisme seringkali dikaitkan dengan terminology tirani lainnya, seperti penindasan, diskriminasi, dan tindakan kebrutalan.

\section{METODE PENELITIAN}

Penelitian ini mencoba untuk menjawab rumusan masalah tentang representasi kulit hitam pada iklan deterjen Qiaobi. Untuk mendapatkan jawaban dari rumusan masalah dalam penelitian ini digunakan metode semiotika. Semiotika mulanya adalah teori bahasa yang diuraikan oleh Ferdinand de Saussure dalam buku yang berjudul Linguistics Course in General (pertama kali diterbitkan pada tahun 1916). Saussure tidak menerima anggapan bahwa bahasa hanya merefleksikan kenyataan dan sebaliknya memberikan saran bahwa bahasa beroperasi dalam sistemnya sendiri.

Sistem ini membuat arti dalam Bahasa - arti tidak berkembang secara sendirinya atau unik. Dia menyebut pendekatan ini dengan semiologi, yang artinya studi tentang tanda, tetapi kita menggunakan istilah yang lebih umum untuk pendekatan ini, yang dikenal sebagai semiotika. Tanda (kata) seperti 'tikus', misalnya, memiliki dua sifat: suara dan gagasan. Tetapi tidak ada hubungan antara suara dan ide: 'pilihan suara tertentu untuk menamai ide yang diberikan benar-benar sewenang-wenang'.

Saussure menyebutkan bahwa tanda bekerja sebagai suatu sistem, tanda-tanda (yaitu kata-kata) yang membuat suatu bahasa bisa menentukan ide-ide dengan tepat karena berbeda dari tanda-tanda lain: 'Bahasa adalah sistem istilah yang saling bergantung di mana nilai setiap istilah dihasilkan semata-mata dari kehadiran simultan dari orang lain. Jadi bahasa terstruktur melalui perbedaan, dan ide yang berbeda bergantung pada suara yang berbeda, atau 'perbedaan fonetik yang memungkinkan untuk membedakan kata ini dari yang lainnya, karena perbedaan membawa arti' (Laughey, 2007).

Oleh karena itu, semiotika berkisar tentang studi tentang tanda dalam teks. Tanda (sign) meliputi dua aspek, yaitu penanda (signifiant), dan petanda (signified). Penanda dapat dimengerti sebagai bentuk/wujud fisik. Penanda bisa berupa bunyi, gambar, huruf, visual dan sejenisnya. Sedangkan petanda adalah konsep atau arti dari apa yang ditandai. Hubungan antara keduanya bersifat "diada-adakan" (arbitrary), yang berarti tidak ada hubungan yang sifatnya alamiah antara penanda dan petanda. Semiotika dengan demikian merupakan relasi tripartit yakni tanda (sign) yang merupakan gabungan dari penanda (signifier) dan petanda (signified) (Hartley, 2003).

Selanjutnya, Saussure mengenalkan tentang langue dan parole. Langue merupakan abstraksi dan artikulasi bahasa pada tingkat sosial budaya, sedangkan parole merupakan ekspresi bahasa pada tingkat individu. Agar lebih mudah memahaminya, langue bisa kita sebut sebagai sistem bahasa yang berlaku, 
sedangkan parole adalah bagaimana individu berbahasa dalam sistem tersebut. Dengan demikian, maka parole terikat dengan langue.

Pemikiran Saussure dikembangkan lebih lanjut oleh Roland Barthes. Barthes memberikan kontribusi penting lainnya untuk memahami peran media dalam reproduksi ideologi. Barthes mengacu pada karya Saussure dan teorinya tentang semiotika, yang telah memasuki dunia media dan penelitian sosial pada tahun 1960-an. Ia berpendapat bahwa pentingnya media dalam penyebaran ideologi atau pandangan dunia berporos pada kemampuan mereka untuk menyusun tanda dan gambaran dengan cara tertentu. Dia meneliti cara di mana tanda-tanda (yaitu, gambar, kata-kata, musik, dan objek) menyampaikan arti yang lebih dalam di dalam masyarakat dan budaya daripada yang tampak secara lahiriah. Secara khusus ia melihat media, melalui proses peartian, membuat arti dan pandangan tertentu dalam masyarakat tampak natural dan masuk akal (Williams, 2003).

Pemikiran Barthes yang berjasa besar dalam arti tanda ialah tentang mitos. Gagasan pemikiran yang sebenarnya masih meneruskan pengandaian Saussure mengenai hubungan bahasa dan arti atau antara penanda dan petanda. Semiotika yang dibangun Saussure cenderung mengatakan arti sebagai apa yang didenotasikan oleh tanda. Dengan demikian, tradisi semiotika pada awal kemunculannya cenderung berhenti sebatas pada arti-arti denotatif alias semiotika denotasi.

Oleh Barthes, gagasan arti denotatif atau peartian di tingkat primer (primary signification) dikaji lebih lanjut. Barthes menyebutkan bahwa ada arti lain yang justru bermain pada level yang lebih mendalam, yakni pada level konotasi atau pengertian sekunder (secondary signification). Dengan begitu, pemikiran Saussure dikembangkan oleh Barthes dengan membongkar praktik pertandaan di tingkat konotasi tanda. Konotasi bagi Barthes justru mendenotasikan sesuatu hal yang ia nyatakan sebagai mitos, dan mitos ini mempunyai konotasi terhadap ideologi tertentu.

Secara operasional dalam penelitian ini semiotika diterapkan dengan melakukan kajian terhadap tanda-tanda yang terdapat dalam iklan deterjen Qiaobi. Iklan deterjen Qiaobi yang diteliti ditempatkan sebagai teks yang merupakan rajutan dari berbagai tanda. Tanda-tanda yang ada baik dalam bentuk gambar, tulisan maupun suara diambil dari shot dan scene yang ada dalam iklan deterjen Qiaobi. Pada tahap hasil penelitian, peneliti menyajikan pengertian secara denotatif dan konotatif, yang kemudian dilanjutkan dengan pembahasan yang menganalisis temuan penelitian dengan intertekstualitas dengan berbagai teori yang relevan.

\section{HASIL PEMBAHASAN}

HASIL

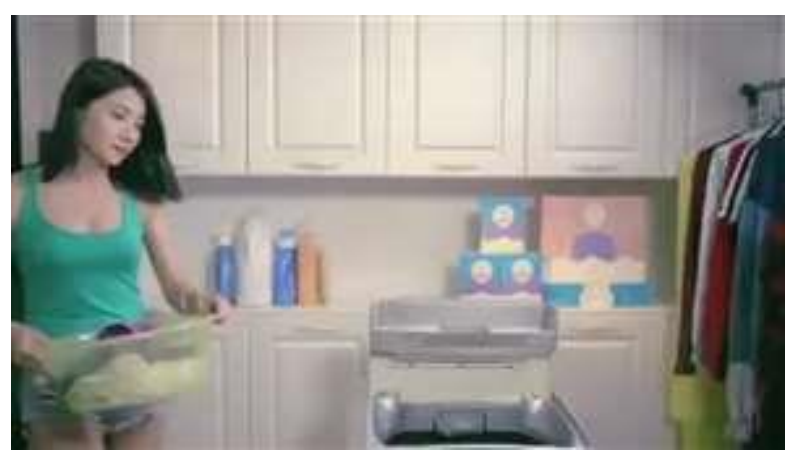

Gambar 1. Scene 1

Makna denotasi: Petanda dalam adegan ini adalah terdapat seorang perempuan berkulit putih dengan pakaian terbuka yang hendak mencuci pakaian di mesin cuci di ruang cuci. Makna konotasi: Aspek 
penanda dalam adegan ini adalah terdapat perempuan berkulit putih yang akan mencuci, talent yang digunakan berkulit putih agar supaya visual yang ditampilkan merepresentasikan stigma dari orang kulit putih.

Mitos: Perempuan berkulit putih dipandang sebagai standar normal dari pemeran iklan. Perempuan masa ini kategorikan dalam pandangan masyarakat sebagai ibu rumah tangga, penilaian masyarakat sekarang untuk perempuan tidak hanya dari kulit yang putih dan bersih, tetapi dari lingkungan dan suasana bersih tempat tinggal perempuan. Lalu terdapat konsep keluarga konvensional, memiliki struktur atau pola relasi dimana suami sebagai pemberi nafkah dan pelindung keluarganya (publik), sedangkan istri sebagai ibu rumah tangga yang mengurus urusan rumah tangga (domestik), yaitu mencuci, memasak, mengasuh anak dan lain-lain (Fadilah et al., 2011). Dari adegan diatas juga dapat menampilkan makna, bahwa perempuan dikonotasikan sebagai manusia feminim, ibu rumah tangga, dan lain-lain. Terlihat dari iklan tersebut bahwa perempuan tadi mencuci pakaian dan bukan laki-laki.

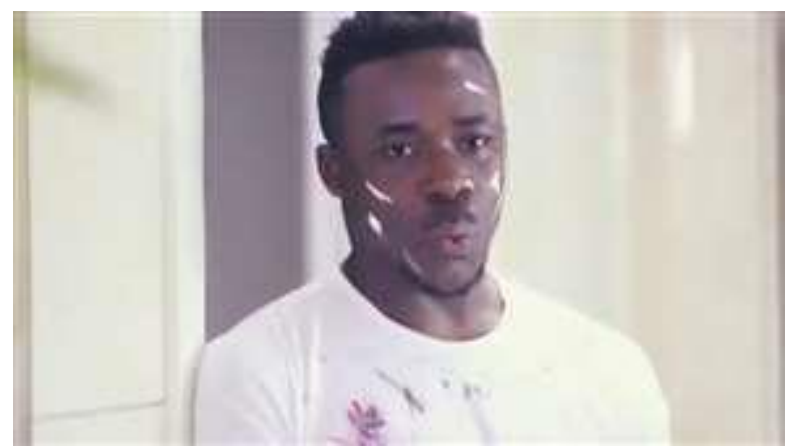

Gambar 2. Scene 2

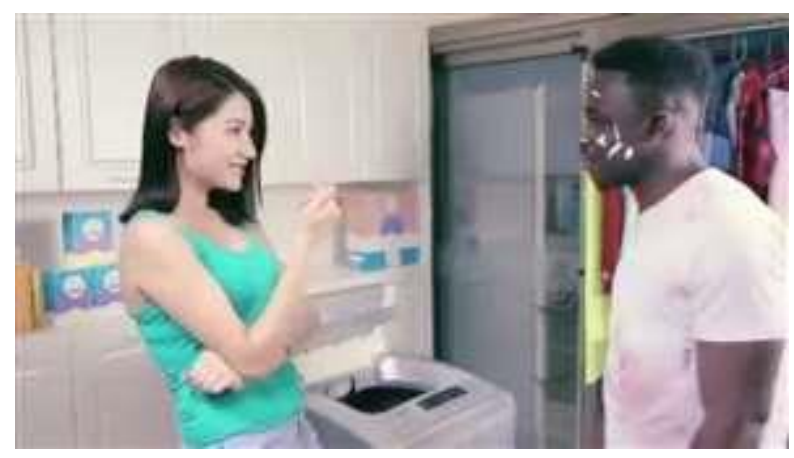

Gambar 3. Scene 2

Makna denotasi: Aspek petanda pada Gambar 2 terlihat seorang laki-laki berkulit hitam dengan coretan di wajahnya sedang bersiul kepada perempuan yang berpakaian terbuka. Pada gambar 3 terlihat perempuan yang sedang mengayunkan tangan dan tersenyum kepada laki-laki tadi. Lalu laki-laki kulit hitam datang dengan senyum di wajahnya.

Makna konotasi: Penanda dari gambar 2 adalah laki-laki kulit hitam yang dipilih, meninjau kembali pandangan masyrakat luas mengenai warga kulit hitam yang memiliki makna negatif. Dalam potongan tersebut, terlihat laki-laki kulit hitam tersebut memiliki ketertarikan pada perempuan dengan pakaian sedikit terbuka. Adegan bersiul pada gambar 2 berarti laki-laki ini menggoda perempuan dengan pakaian sedikit terbuka sebagai bentuk ambisi kuasa laki-laki atas perempuan. Lalu terdapat coretan warna putih di wajah laki-laki berkulit hitam ini sehingga membuat kesan negatif malah semakin kuat.

Lalu pada gambar 3 adalah wanita sebagai objek seksualitas laki-laki. Seperti persepsi yang berkembang di masyarakat sekarang, wanita selalu saja menjadi sebuah objek yang mudah sekali ditelanjangi baik dari 
sisi manapun. Hal ini ditunjukan dengan banyaknya korban pelecehan seksual yang kebanyakan korbannya merupakan perempuan. Seperti yang ditunjukan pada adegan diatas, bahwa perempuanlah yang menjadi objek. Perempuan dengan pakaian terbuka merupakan perempuan yang mudah untuk digoda. Pada adegan setelah laki-laki ini bersiul, perempuan ini langsung tersenyum dan mengayunkan tangannya untuk mengajak laki-laki tadi untuk mendekat.

Mitos: Kulit hitam dianggap identik dengan kaum marjinal, kumuh, dan tidak berpendidikan. Perempuan dengan pakaian terbuka dapat menarik perhatian lawan jenis begitu pula laki-laki yang harus memiliki wajah yang putih dan tampan agar terlihat menarik bagi perempuan. Tubuh perempuan memiliki kelebihan yang dapat memikat lawan jenis. Hal ini dikarenakan tubuh perempuan dipercaya memiliki suatu efek yang dapat menimbulkan hasrat seksual terhadap lawan jenis. Hal tersebut dapat dibuktikan ketika lawan jenis melihat beberapa anggota tubuh milik perempuan yang dianggap dapat memicu hasrat seksual lawan jenis. Contohnya adalah perempuan-perempuan Latin yang digambarkan oleh media yang berkonotasi dengan seks dan seksualitas. Misalnya, Sports Illustrated edisi Musim Dingin 2002 menampilkan model berbikini Yamila Diaz-Rahi di sampulnya (Sataloff et al.2013.).

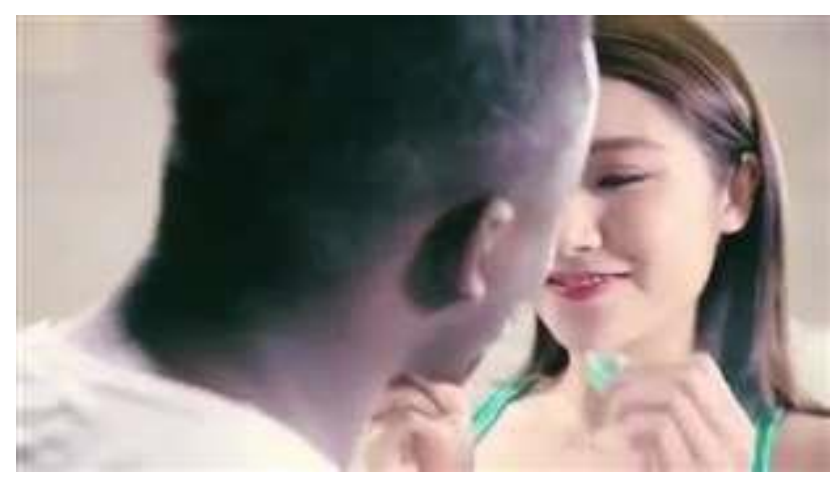

Gambar 4. Scene 3

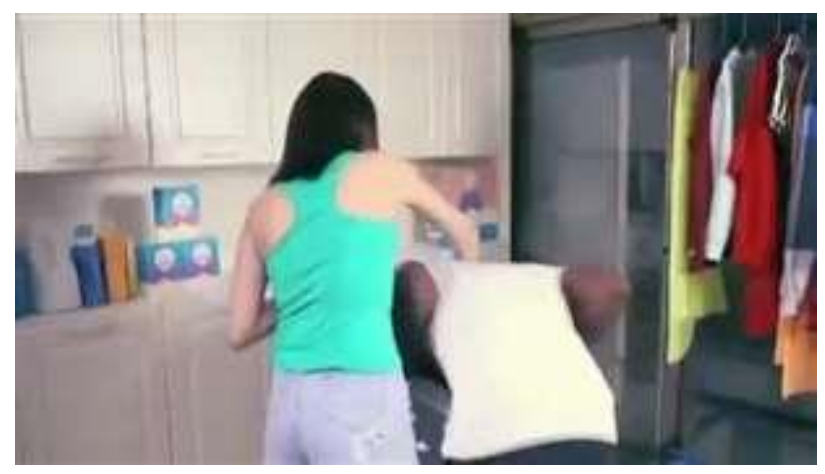

Gambar 5. Scene 3

Makna denotasi: terlihat seorang laki-laki berkulit hitam yang hendak mencium perempuan berkulit putih. Lalu perempuan berkulit putih tadi hendak memasukan 1 wadah deterjen ke mulut laki-laki berkulit hitam. Lalu pada gambar 5 perempuan ini memasukan laki-laki berkulit hitam ke dalam mesin cuci untuk dicuci.

Makna donotasi: Aspek penanda dari gambar tersebut adalah terlihat perempuan tersebut berniat untuk membersihkan tubuh laki-laki berkulit hitam dikarenakan tubuh laki - laki kulit hitam tersebut berkulit hitam dan terdapat noda-noda putih. Hal ini menguatkan makna jika perempuan tidak menyukai laki-laki berkulit hitam. 
Mitos: berbagai segelintir orang melihat Kulit hitam itu kotor dan dibenci. Pandangan segelintir orang terhadap warna memberikan andil dalam membentuk pemikiran bahwa sesuatu yang putih atau terang merepresentasi sesuatu berunsur suci, bersih, dan baik. Sementara itu, hitam atau gelap merepresentasi sesuatu yang kotor, jahat, dan tidak baik (Thompson, 2006:48). Hal ini juga menyebabkan orang - orang kulit putih lebih disukai, sementara orang-orang kulit hitam dijauhi dan dibenci (Evelyn et al., 2019),

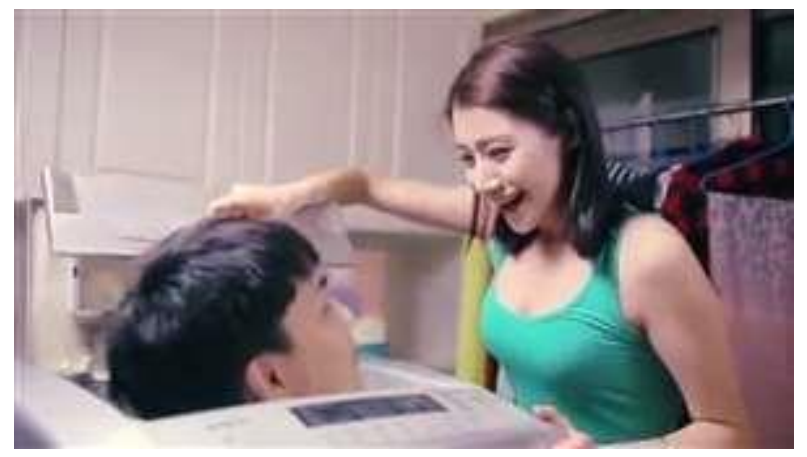

Gambar 6. Scene 4

Makna denotasi: Aspek petanda pada adegan ini adalah seorang perempuan berkulit putih dengan senyum lebar di wajahnya saat melihat laki-laki berkulit putih yang keluar dari mesin cuci. Senyum lebar yang diekspresikan dari perempuan tersebut menunjukkan rasa senang dan juga takjub dengan laki-laki berkulit hitam menjadi putih saat baru saja dicuci dengan deterjen qiaobi menggunakan mesin cuci.

Makna konotasi: Perempuan tersebut senang dikarenakan laki - laki yang tadinya berkulit hitam dan berpakaian kotor, sekarang menjadi putih dan bersih. Hal ini dikarenakan perempuan lebih menyukai laki - laki tampan berkulit putih, berpakaian rapi daripada laki - laki berkulit hitam yang terkesan kotor dan memiliki tampilan seperti seorang dengan tampang dekil dan kotor. Hal ini yang membuat stereotipe di mana perempuan lebih suka dengan laki-laki berkulit putih ketimbang laki-laki berkulit hitam.

Mitos: Masyarakat berstigma kalau laki-laki yang menarik adalah laki-laki yang berkulit putih. Stigma ini pada akhirnya menjad sebuah stereotip. Perempuan lebih menyukai dan mengidolakan kulit putih dibandingkan kulit hitam, hal ini dipengaruhi oleh ideologi white supremacy, di mana kulit putih dipandang lebih superior dan unggul, dibandingkan kulit hitam yang dianggap inferior dan tidak unggul. Fenomena ini sudah terjadi dari pengenalan perbudakan Amerika pada tahun 1619 hingga upaya terorganisir untuk menempatkan status sosial yang lebih rendah pada orang kulit hitam selama era Jim Crow, hal ini terjadi selama berabad - abad, bahkan sampai saat ini (Riley, 2011).

\section{PEMBAHASAN}

Orang kulit putih atau ras kulit putih sering digambarkan sebagai ras paling sempurna oleh media. Pada iklan Deterjen Qiaobi ini Di dalam iklan sering kali ras kulit putih ditampilkan daripada ras kulit hitam, hal ini dikarenakan ras putih dijadikan sebagai pembeda dari pandangan seseorang di masyarakat. Pandangan masyarakat terhadap warna kulit memberikan andil dalam membentuk pemikiran bahwa putih atau terang merepresentasi sesuatu yang suci, bersih, dan baik. Perempuan lebih menyukai dan mengidolakan kulit putih dibandingkan kulit hitam, hal ini dipengaruhi oleh ideologi white supremacy, di mana kulit putih dipandang lebih superior dan unggul, dibandingkan kulit hitam yang dianggap inferior dan tidak unggul. Hal ini juga disebutkan oleh Parker dan Lynn (2002), bahwa salah satu tujuan teori kritis ras adalah menyajikan kisah tentang diskriminasi yang bersumber perspektif masyarakat tentang warna. 
Secara historis orang-orang kulit hitam juga pernah mengalami masa-masa yang suram dan masa masa aib bagi mereka. Warna kulit mereka pernah menjadi semacam musuh bersama dari kaum kulit putih. Mereka diperangi dan dihina sebagai kaum yang terlahir dari golongan purba. Hal ini diperkuat dengan Teori Ras kritis yang memfokuskan perhatian pada isu-isu ras dan bagaimana tindakan rasis secara mendalam tertanam dalam kerangka kerja masyarakat Amerika (Parker dan Lynn, 2002). Dengan jenisjenis iklan tertentu, sebagian dari rasisme sedang berlangsung, namun dengan cara yang lebih halus dan lembut. Sejujurnya rasisme terhadap ras kulit hitam sudah sering terjadi, hanya saja dengan senjata dan stategi yang berbeda. Dulu barangkali senjatanya adalah pedang dan senapan, tapi sekarang tidak, kekuatannya terletak pada pembentukan citra dan makna, yang terkadang menghipnotis khalayak melalui iklan di media massa.

Dalam hal ini persoalannya bukan hanya terletak pada produk iklan yang dipasarkan, tapi lebih kepada konstruksi sebuah pemasaran yang disertakan pada produk yang diiklankan. Hanya karena warna kulit menjadi hitam saat berjemur, dicitrakan seolah-olah kulit menjadi hitam bagaikan sebuah aib yang perlu dibersihkan. Pemahaman ini pula yang menunjukkan bahwa posisi kulit hitam dalam iklan sangat rendah dan lebih tinggi dari orang-orang kulit putih. Hal ini Kulit hitam dianggap rendah dan tidak dihormati posisinya, sehingga ia mendapat perlakuan tersebut.

Di sinilah perlu adanya sikap ketelitian dari para pihak-pihak yang punya kuasa untuk menyensor iklan-iklan yang mengandung unsur rasis yang merendahkan ras tertentu dan lebih dari itu yang bisa menyerang psikologis seseorang karena pemahaman banyak orang yang berpikir bahwa kulit hitam itu adalah aib sehingga punya bahaya yang bisa mengancam nilai-nilai sosial dan kemanusian. Melalui rasisme dan tindakan ketidakadilan sosial lainnya yang ada pada kulit hitam, membuat berbagai kelompok yang lebih dominan dari kelompok lainnya menciptakan pola historis dominasi dan subordinasi berdasarkan ras, hal ini menempatkan orang-orang kulit hitam diperlakukan sebagai bawahan dari orang-orang kulit putih yang tidak berdaya.

\section{KESIMPULAN}

Perempuan adalah ibu rumah tangga yang hanya boleh mengurus rumah tangga. Konsep keluarga konvensional, memiliki struktur atau pola relasi dimana suami sebagai pemberi nafkah dan pelindung keluarganya (publik), sedangkan istri sebagai ibu rumah tangga yang mengurus urusan rumah tangga (domestik), yaitu mencuci, memasak, mengasuh anak dan lain-lain.

Perempuan dengan pakaian terbuka dapat menarik perhatian laki-laki. Tubuh perempuan memiliki kelebihan yang dapat memikat lawan jenis. Hal ini dikarenakan tubuh perempuan dipercaya memiliki suatu efek yang dapat menimbulkan hasrat seksual terhadap lawan jenis. Hal tersebut dapat dibuktikan ketika lawan jenis melihat beberapa anggota tubuh milik perempuan yang dianggap dapat memicu hasrat seksual lawan jenis. Contohnya adalah perempuan-perempuan Latin yang digambarkan oleh media yang berkonotasi dengan seks dan seksualitas.

Pandangan masyarakat terhadap warna kulit memberikan andil dalam membentuk pemikiran bahwa putih atau terang merepresentasi sesuatu yang suci, bersih, dan baik. Perempuan lebih menyukai dan mengidolakan kulit putih dibandingkan kulit hitam, hal ini dipengaruhi oleh ideologi white supremacy, di mana kulit putih dipandang lebih superior dan unggul, dibandingkan kulit hitam yang dianggap inferior dan tidak unggul. 


\section{PERSANTUNAN}

Artikel ini disusun sebagai bagian dari tugas kuliah Kajian Kritis Iklan di Program Studi Ilmu Komunikasi Universitas Muhammadiyah Yogyakarta tahun akademik 2020/2021. Tim penulis menghaturkan terima kasih kepada Dr. Fajar Junaedi, dosen pengampu mata kuliah yang telah membantu dan mendukung penulis selama proses penelitian ini berlangsung sampai dengan terbitnya publikasi atas hasil penelitian ini.

\section{REFERENSI}

Chaiklin, H. (2005). The Psychology of Stereotyping. In The Journal of Nervous and Mental Disease (Vol. 193, Issue 10). https://doi.org/10.1097/01.nmd.0000180748.87223.92

Evelyn, A., Priyowidodo, G., Ë Budiana, D. (2019). Representasi Rasisme dalam Film Woodlawn. 7(1), 1-13. http://publication.petra.ac.id/index.php/ilmu-komunikasi/article/view/9686

Fadilah, A. N., Kurniasari, N. D., E Quraisyin, D. (2011). Relasi Gender dalam Hubungan Pacaran. Komunikasi, 5(2), 79-164.

Hartley, J. (2003). A short history of cultural studies. A Short History of Cultural Studies, 1-189. https://doi.org/10.4135/9781446216934

Kite, M. E., EB Whitley, Jr., B. E. (2020). Age, Ability, and Appearance. In Psychology of Prejudice and Discrimination. https://doi.org/10.4324/9781315623849-19

Laughey, D. (2007). Key themes in media theory. Key Themes in Media Theory, 1-29.

Maiti, E⿱E Bidinger. (1981). 済無No Title No Title. Journal of Chemical Information and Modeling, 53(9), 16891699.

Nurhayati, A. (2019). Intersecting Oppression of Gender and Race. Litera, 8(3), 379-394.

Riley, J. R. (2011). 済無No Title No Title. In Journal of Chemical Information and Modeling (Vol. 53, Issue 9).

Sataloff, R. T., Johns, M. M., G Kost, K. M. (n.d.). No 主観的健康感を中心とした在宅高齢者における 健康関連指標に関する共分散構造分析Title.

Umarela, F. H., Dwityas, N. A., Ë Zahra, D. R. (2020). Representasi ideologi supremasi kulit putih dalam iklan televisi. ProTVF, 4(1), 64. https://doi.org/10.24198/ptvf.v4i1.25172

Williams, K. (2003). Understanding Media Theory. 266.

Chaiklin, H. (2005). The Psychology of Stereotyping. In The Journal of Nervous and Mental Disease (Vol. 193, Issue 10). https://doi.org/10.1097/01.nmd.0000180748.87223.92

Evelyn, A., Priyowidodo, G., Ë Budiana, D. (2019). Representasi Rasisme dalam Film Woodlawn. 7(1), 1-13. http://publication.petra.ac.id/index.php/ilmu-komunikasi/article/view/9686

Fadilah, A. N., Kuniasari, N. D., Eु Quraisyin, D. (2011). Relasi Gender dalam Hubungan Pacaran. Komunikasi, 5(2), 79-164.

Hartley, J. (2003). A short history of cultural studies. A Short History of Cultural Studies, 1-189. https://doi.org/10.4135/9781446216934

Kite, M. E., $\mathcal{G}$ Whitley, Jr., B. E. (2020). Age, Ability, and Appearance. In Psychology of Prejudice and Discrimination. https://doi.org/10.4324/9781315623849-19

Laughey, D. (2007). Key themes in media theory. Key Themes in Media Theory, 1-29.

Maiti, E Bidinger. (1981). 済無No Title No Title. Journal of Chemical Information and Modeling, 53(9), 16891699.

Nurhayati, A. (2019). Intersecting Oppression of Gender and Race. Litera, 8(3), 379-394.

Riley, J. R. (2011). 済無No Title No Title. In Journal of Chemical Information and Modeling (Vol. 53, Issue 9).

Sataloff, R. T., Johns, M. M., E Kost, K. M. (n.d.). No 主観的健康感を中心とした在宅高齢者における 健康関連指標に関する共分散構造分析Title. 
Umarela, F. H., Dwityas, N. A., Eु Zahra, D. R. (2020). Representasi ideologi supremasi kulit putih dalam iklan televisi. ProTVF, 4(1), 64. https://doi.org/10.24198/ptvf.v4i1.25172

Williams, K. (2003). Understanding Media Theory. 266.

Parker, L., EF Lynn, M. (2002). What's Race Got to Do With It? Critical Race Theory's Conflicts With and Connections to Qualitative Research Methodology and Epistemology. Qualitative Inquiry, 8, 22 - 7. 